\title{
Targeting Apolipoprotein E for Alzheimer's Disease: An Industry Perspective
}

\author{
Georgette L. Suidan and Gayathri Ramaswamy * \\ Alzheimer's Disease and Dementia Research Unit, Biogen Inc., Cambridge, MA 02142, USA; \\ Georgette.Suidan@biogen.com \\ * Correspondence: Gayathri.Ramaswamy1@biogen.com
}

Received: 24 March 2019; Accepted: 28 April 2019; Published: 1 May 2019

\begin{abstract}
Apolipoprotein E (apoE), a key lipid transport protein in the brain, is predominantly produced by astrocytes. Astrocytes are the most numerous cell type in the brain and are the main support network for neurons. They play a critical role in the synthesis and delivery of cholesterol in the brain. Humans have three common apoE isoforms, apoE2, apoE3 and apoE4, that show a strong genotype effect on the risk and age of onset for sporadic and late onset forms of Alzheimer's disease (AD). Carriers of an $\varepsilon 4$ allele have an increased risk of developing AD, while those with an $\varepsilon 2$ allele are protected. Investigations into the contribution of apoE to the development of AD has yielded conflicting results and there is still much speculation about the role of this protein in disease. Here, we review the opposing hypotheses currently described in the literature and the approaches that have been considered for targeting apoE as a novel therapeutic strategy for AD. Additionally, we provide our perspective on the rationale for targeting apoE and the challenges that arise with respect to "drug-ability" of this target.
\end{abstract}

Keywords: apolipoprotein E; Alzheimer's disease; astrocytes

\section{Introduction}

Alzheimer's disease (AD) is the leading cause of dementia in elderly people. Hallmarks of the disease include the deposition of amyloid beta $(\mathrm{A} \beta)$ plaques and the presence of neurofibrillary tangles. Thus, strategies that have gained the most traction in the field are predominantly focused on targeting amyloid and tau proteins [1,2]. However, Alois Alzheimer also reported the presence of "adipose inclusions" as one of the pathologies in the AD brain, in addition to amyloid and tau, suggesting that $\mathrm{AD}$ brains display signs of aberrant lipid metabolism [3,4]. Emerging data clearly indicate a strong link between $\mathrm{AD}$ and lipids. In fact, the brain is the most lipid-rich organ in the body and-despite accounting for about $2.1 \%$ of the total body weight-contains about $25 \%$ of total body sterols. In the central nervous system (CNS), lipids play a critical role in both structure and function $[5,6]$. For example, unesterified cholesterol plays a specialized role as the major architectural component of the myelin sheath. In fact, about $70 \%$ of total brain cholesterol is present in the myelin sheath. The remaining lipids are present in functionally active pools in neurons and glia. During CNS development, required cholesterol and lipid pools are obtained exclusively from de novo synthesis. Whether there is any influence of plasma lipids on the brain lipid pool is currently unknown. Given such a crucial role of lipids in the CNS, maintaining lipid homeostasis in the brain is critical for maintaining a healthy state. It is therefore not surprising that changes in lipid metabolism in the brain can lead to neurodegenerative diseases. However, the most important association was established in 1994 with the discovery of a profound role for apolipoprotein $\mathrm{E}(\mathrm{apoE})$ in $\mathrm{AD}[7]$.

Astrocytes are the predominant producers of apoE in the brain $[8,9]$. In addition to astrocytes, microglia and neurons have also been shown to synthesize apoE $[8,10]$. ApoE plays an important 
role in lipid transport to neurons [11,12], synaptogenesis [13], cerebrovascular integrity and cerebral blood flow (CBF) [14,15], hippocampal neurogenesis [16], neuroimmune modulation [17] and amyloid clearance $[18,19]$. The three common human isoforms, apoE2, apoE3 and apoE4, differ from each other at amino acid positions 112 and 158. ApoE2 has cysteine (Cys) in these two positions, apoE3 has Cys at 112 and arginine (Arg) at 158 and apoE4 has Arg in both positions [20]. These small amino acid differences in the apoE isoforms elicit a profound genotype-dependent effect on apoE function, such as lipid transport and amyloid clearance, among others [20]. Importantly, these three common human apoE isoforms show a strong genotype effect on the risk and age of onset for sporadic and late onset forms of Alzheimer's disease (LOAD), with apoE4 being the strongest known genetic risk factor for AD.

Despite numerous new genome-wide association studies (GWAS) findings that have been reported, after age, apoE4 is still the strongest known risk factor for AD. While several hypotheses have been proposed, the exact mechanism by which apoE4 contributes to $\mathrm{AD}$ is not known. Consequently, there is significant debate on whether apoE should be upregulated or downregulated, with reports showing both protective and pathological roles of apoE4. The goal of this review is to describe the approaches that have been considered to target apoE as a novel therapeutic strategy for AD.

\section{Opposing Hypotheses on the Contribution of ApoE4 to AD}

\subsection{Loss of Function}

ApoE4 has been suggested to be poorly lipidated relative to apoE2 and apoE3. ApoE protein levels in human cerebrospinal fluid (CSF) are reduced in $\varepsilon 4$ carriers compared to $\varepsilon 2$ and $\varepsilon 3$ by $\sim 30 \%$ [21], and the levels of lipid-depleted apoE in $\varepsilon 4$ carriers is elevated $\sim 2$-fold [22]. Similar results were found in mice expressing human isoforms of apoE. Utilizing mass spectroscopy and enzyme-linked immunosorbent assay (ELISA) methods, it was shown that apoE4-expressing mice have significantly less apoE in their plasma, brain and CSF compared to apoE2 and apoE3 [23]. Proper lipidation of astrocytic apoE to form high-density lipoprotein (HDL)-like particles is essential for its stability and proper function; thus, it is hypothesized that poor lipidation of apoE4 leads to reduced function and downstream pathology $[24,25]$. Lipidation of apoE in astrocytes is carried out primarily by the adenosine triphosphate (ATP)-binding cassette family member, abca1. Indeed, ATP-binding cassette transporter a1 (abca1) knock-out mice showed reduced levels of brain apoE and lipidated apoE particles in their CSF [25]. These mice have also shown reduced dendritic density in the CA1 region of the hippocampus [26] and increased amyloid burden in the brain when crossed with human amyloid precursor protein (APP)-overexpressing mice [27]. Interestingly, a large scale population study found that a loss-of-function variant of abca1 in humans resulted in reduced plasma apoE and increased risk of $\mathrm{AD}$, cerebrovascular disease and hemorrhagic stroke, suggesting that this mechanistic axis should also be considered for improvement of cerebrovascular health and function [28]. In contrast, abca1 overexpression in mice increases lipidation of apoE and enhances amyloid clearance [29]. Increasing astrocytic abca1 expression and the resulting increase in apoE lipidation has been shown to have beneficial effects on axonal damage in a traumatic brain injury mouse model [30,31]. An elegant study was recently published utilizing astrocytes derived from human inducible pluripotent stem cells (iPSCs) with either $\varepsilon 3 / \varepsilon 3$ or $\varepsilon 4 / \varepsilon 4$ genotypes, which provided further evidence in human cells that secreted apoE4 is poorly lipidated. Interestingly, astrocytes derived from an $\varepsilon 4 / \varepsilon 4$ patient cells did not support neuronal survivalas well as $\varepsilon 3 / \varepsilon 3$, further supporting the idea that the reduced lipidation state of apoE4 is tied to neuronal health [32]. Additionally, HDLs have been shown to enhance amyloid clearance through the blood-brain barrier and reduce vascular inflammation, and therefore enhancing apoE lipidation has the potential to be protective to the cerebrovasculature $[33,34]$. Further supporting data for the apoE4 loss of function hypothesis are the pathological similarities reported between apoE4 and apoE knockout (KO) mice. For example, both strains of mice were shown to have reduced levels of synaptic proteins PSD-95, GKAP and synaptophysin compared to wild-type and apoE3 
mice [15]. The inflammatory response of apoE4 mice was similar to apoE KO when challenged with lipopolysaccharide [17]. Further, work in mice that express human apoE isoforms and five familial AD mutations (termed EFAD) concluded that having apoE4 or no apoE leads to increased age-dependent cognitive dysfunction and reduction in synaptic proteins when compared to mice expressing apoE2 or apoE3 [35]. These data collectively support a reduction in function of apoE4 compared to apoE3 or apoE2 and suggest that therapies focused on enhancing the lipid-transporting function of apoE4 would be beneficial for disease treatment.

\subsection{Gain of Toxicity}

There are several lines of evidence that support the hypothesis that the apoE4 protein plays a toxic role in the disease state. Although, the important role of astrocyte-derived apoE under physiological conditions is not disputed, the potential for apoE (in particular, apoE4) to take on a determinantal role under disease-like conditions has been demonstrated in several animal models. Cerebral ischemia has been shown to lead to expression of apoE in neurons, a phenomenon not detected in control rats [36]. Neuronal-expressed apoE4 is subject to cleavage, resulting in the generation of neurotoxic apoE fragments [37,38]. The identity of the enzyme that cleaves neuronal apoE is unknown, but data support that it is a chymotrypsin-like serine protease $[39,40]$. Targeting the cleavage of neuronal apoE is a proposed therapeutic approach for AD [41]. Interestingly, it has been determined that astrocyte-derived apoE is not subject to cleavage, suggesting that this therapeutic approach would be specific to neuronal apoE [42]. Further support for this hypothesis was reported in mice expressing the human apoE isoforms crossed with mice which develop tau pathology. ApoE KO mice were protected, whereas apoE4 mice had worsened pathology, suggesting that the apoE4 protein in these mice was exerting a toxic effect [43]. One hypothesis of how apoE4 promotes pathology in AD is through the initial seeding of $A \beta$ [44]. An apoE-inducible expression mouse model bred with a mouse strain expressing the human amyloid precursor protein and presenilin with human mutations (APP/PS) was used to demonstrate that increasing expression of astrocytic human apoE4 enhanced amyloid deposition in mice when expression was turned on prior to initial seeding [45]. These findings were not present in the apoE3 expressing mice, indicating that apoE4 specifically plays a role in seeding of human $A \beta$ [45]. Other reports suggest that apoE4 exerts its toxic effects through diminished receptor recycling due to disruption of endocytic transport. Indeed, it has been shown that apoE4 reduces recycling of critical glutamate receptors ( $\alpha$-amino-3-hydroxy-5-methyl-4-isoxazoleproprionic acid and $N$-methyl-D-aspartate) and apoE receptors which leads to synaptic dysfunction [46,47]. Others have shown that treatment of apoE knock-out neurons with recombinant and lipidated apoE4 leads to an accumulation of insulin receptors in the endosome, which, in turn, reduces mitochondrial respiration and glycolysis [48]. These data supported in vivo work indicating that insulin signaling in the brain was impaired in aged apoE4 target replacement mice [48]. ApoE4 expressed in GABA-ergic neurons was shown to result in memory and cognitive deficits in mice [49]. Additionally, astrocyte-mediated synaptic pruning has been shown to be allele-dependent, with apoE4 astrocytes demonstrating reduced phagocytic capacity, whereas apoE KO astrocytes were similar to apoE3 and wild-type astrocytes, suggesting a gain-of-toxic function of apoE4 [50]. Together, these data support a detrimental role for apoE4 in disease and suggest that therapeutic intervention should focus on removing or altering this toxic isoform.

\section{Approaches for Targeting ApoE in AD}

Although not as mainstream as amyloid and tau approaches, there are approaches for targeting apoE in Alzheimer's disease being undertaken in academia and industry (Table 1). There are several unique strategies for targeting apoE and clear indecision about the contribution of apoE4 to $\mathrm{AD}$ pathology, as mentioned in the previous sections. Below, we highlight some of the latest findings in the field, with the exception of gene therapy and mimetic peptide approaches, which are very intriguing and reviewed nicely elsewhere [51]. 
Table 1. Overview of approaches for targeting apolipoprotein E (apoE) for Alzheimer's disease (AD).

\begin{tabular}{|c|c|c|c|}
\hline Approach & Rationale & Institution/Company & Risks/Gaps \\
\hline $\begin{array}{l}\text { Bexarotene (RXR agonist; } \\
\text { cancer drug-Targetin). }\end{array}$ & $\begin{array}{c}\text { Increase lipidation of } \\
\text { apoE. }\end{array}$ & $\begin{array}{c}\text { Indiana } \\
\text { University/ADDF [19]. }\end{array}$ & $\begin{array}{l}\text { Safety issues due to RXR agonist } \\
\text { and impaired brain exposure [52]. }\end{array}$ \\
\hline $\begin{array}{c}\text { Abca1 peptide agonist } \\
\text { (derived from } \\
\text { carboxy-terminal of apoE). }\end{array}$ & $\begin{array}{l}\text { Increase lipidation of } \\
\text { astrocytic apoE4. }\end{array}$ & $\begin{array}{c}\text { Tel Aviv } \\
\text { University/Artery } \\
\text { Therapeutics [53]. }\end{array}$ & $\begin{array}{l}\text { Unclear mechanism by which the } \\
\text { peptide agonist activates Abca1, a } \\
\text { transmembrane protein. }\end{array}$ \\
\hline $\begin{array}{l}\text { ApoE4 structure } \\
\text { correctors. }\end{array}$ & $\begin{array}{l}\text { Convert neuronal apoE4 } \\
\text { to apoE3-like molecule. } \\
\text { Mitigate neuronal } \\
\text { toxicity caused by apoE4 } \\
\text { fragments. }\end{array}$ & $\begin{array}{c}\text { Gladstone } \\
\text { Institute/E-Scape bio } \\
{[54,55] .}\end{array}$ & $\begin{array}{l}\text { Based on the premise that neurons } \\
\text { express apoE. Effect on astrocytic } \\
\text { apoE or apoE lipidation unknown. }\end{array}$ \\
\hline ApoE antibody. & $\begin{array}{l}\text { Target unlipidated apoE } \\
\text { associated with amyloid } \\
\text { plaques. Increase } \\
\text { amyloid clearance. }\end{array}$ & $\begin{array}{l}\text { Washington } \\
\text { University/Denali } \\
\text { therapeutics [56]. }\end{array}$ & $\begin{array}{l}\text { Based on the premise that } \\
\text { unlipidated apoE in associated } \\
\text { with plaques. Amount or origin of } \\
\text { unlipidated apoE in the brain } \\
\text { unknown. }\end{array}$ \\
\hline $\begin{array}{l}\text { ApoE anti-sense } \\
\text { oligonucleotide. }\end{array}$ & $\begin{array}{l}\text { Reduce expression of } \\
\text { apoE4 in the CNS. }\end{array}$ & $\begin{array}{c}\text { Washington } \\
\text { University/Ionis [57]. }\end{array}$ & $\begin{array}{l}\text { Based on the premise that apoE4 is } \\
\text { toxic. Safety needs to be assessed } \\
\text { as effect of chronic knockdown of } \\
\text { apoE4 is not known. }\end{array}$ \\
\hline
\end{tabular}

\subsection{Correcting the Structure of ApoE4}

Using biophysical and biochemical methods, it has been demonstrated that the presence of Arg at amino acid position 112 in apoE4, instead of Cys 112 as seen in apoE3, results in an interaction between the amino-terminal low density lipoprotein receptor binding domain and the carboxy-terminal lipid binding domain via a salt bridge, leading to a property called domain interaction [58]. Domain interaction has been shown to be responsible for lower levels of secretion of apoE4 from astrocytes relative to apoE3 [59,60]. Additionally, investigators from the Gladstone Institute have shown that when apoE4 is expressed in neurons under stress, domain interaction is responsible for proteolysis of neuronally expressed apoE4 into neurotoxic fragments $[6,39,58]$. Domain interaction-mediated apoE4 proteolysis was found to result in mitochondrial dysfunction in neurons [41]. Small molecule structure correctors that interfere with this property and convert apoE4 to an apoE3-like molecule have been reported to mitigate the neurotoxic effects [54,55]. Importantly, data generated with structure correctors have exclusively focused on the neuron-expressed pool of apoE, rather than astrocyte-derived. Additional work is necessary to understand the relevance of this strategy for astrocyte-derived apoE4 which does not undergo proteolysis [42]. Whether these structure correctors would increase lipidation of astrocytic apoE4 is also currently unknown. Furthermore, the feasibility of utilizing a small molecule to correct the structure of a secretory protein that undergoes dynamic lipidation processes remains to be seen. Development of small molecule allosteric modulators of apoE4 structure for targeting apoE4-mediated pathology is an interesting strategy and is being pursued commercially by eScape Bio.

\subsection{Increasing ApoE Lipidation via Abca1}

Abca1 has been shown to be critical for apoE lipidation [25]. Most known mechanisms regulating expression of abca1 are driven by nuclear hormone receptors, such as liver-X-receptor (LXR)and retinoid-X-receptor (RXR) Indeed, treatment of human astrocytes with small molecule agonists of LXR and RXR results in increased abca1 protein levels in the brain and lipidation of CNS apoE [18,19,61,62]. Hepatic $L X R \alpha$ activation is a key toxicity associated with these nuclear hormone receptor agonists, resulting in fatty liver and increased plasma triglyceride levels in mice [63]. Recently, pan class I histone deacetylase (HDAC) inhibition was shown to increase astrocytic apoE and abca1 in an LXR-independent manner [64]. However, selectivity issues intrinsic to HDAC inhibitors make this class of molecules unattractive for developing therapeutics. Importantly, several groups have demonstrated 
that lipidation of apoE4 can be achieved pharmacologically, a critical finding when considering this approach to targeting apoE in AD [53]. For example, a direct peptide activator of abca1, CS-6253, has been reported by Artery Therapeutics and researchers at Tel Aviv University to increase lipidation of apoE4 in mouse brain tissue. Further, treatment with this agonist reversed $A \beta 42$ deposition and tau hyperphosphorylation in apoE4-targeted replacement mice [53], suggesting that increasing apoE4 lipidation via abca1 activation could overcome the pathological effects of the apoE4 allele. These data further support work showing that enhancement of apoE4 lipidation can be achieved through nuclear hormone receptor-independent mechanisms. Additionally, a novel chrysanthemic ester was identified that upregulated apoE in fibroblasts deficient in $\mathrm{LXR} \alpha$ and $\mathrm{LXR} \beta$, indicating an LXR-independent mechanism [65]. Therefore, increasing apoE lipidation is an attractive approach with multi-prong benefits (Figure 1).

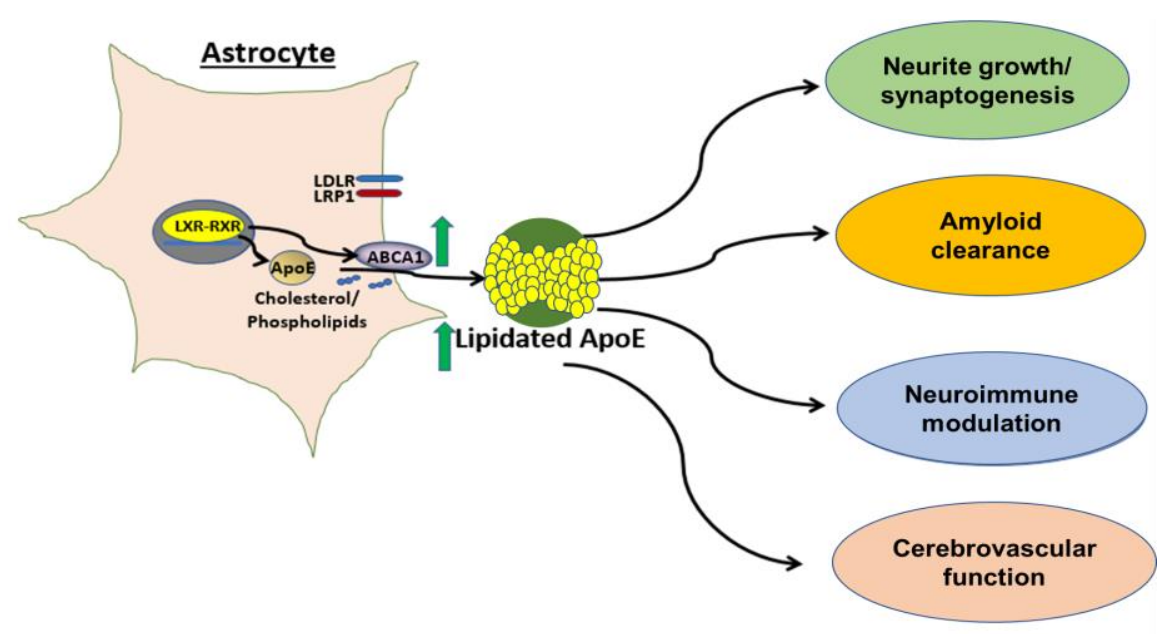

Figure 1. Increasing lipidation of the astrocytic pool of apoE. Astrocytes are the primary producer of apoE in the brain. Common mechanisms of apoE and abca1 expression are driven by nuclear hormone receptor (such as LXR and RXR) activation. Abca1 is critical for lipidation of apoE and increasing expression of abca1 leads to increased lipidation of all apoE isoforms (indicated by green arrows). We hypothesize that increasing apoE lipidation will be beneficial for several AD-relevant endpoints.

\subsection{Clearing Non-Lipidated ApoE}

Recently, an approach was published in which antibodies targeting aggregated, non-lipidated apoE4 were found to reduce amyloid plaques in an APP/PS mouse model crossed with apoE4 knock-in (KI) mice. These studies were the first to show preclinical efficacy with an antibody specific to the non-lipidated form of apoE3 and apoE4 [56]. Currently, it is unknown what the levels and cellular origin of non-lipidated apoE are in the brain and CSF of apoE4 carriers. Interestingly, one study determined that "lipid-depleted" apoE was increased in apoE4 carrier CSF. Whether these antibodies would bind "lipid-depleted" apoE is unknown. The current hypothesis is that this antibody mediates a protective effect through binding of apoE in plaque and inciting a microglial response, leading to clearance. Despite many unanswered questions, this is a novel and interesting approach for targeting apoE.

\subsection{Reducing Expression of ApoE4}

As the gain-of-toxicity hypothesis suggests a deleterious role for apoE4, reducing expression of this protein in the brain is an approach being undertaken. Recently, a study was published that utilized anti-sense oligonucleotide technology to reduce apoE in APP/PS mice crossed with either human apoE3 or apoE4 KI mice. Approximately $50 \%$ knockdown of apoE starting at birth resulted in $~ 50 \%$ reduction of plaque area and fibrillar plaque load [57]. Interestingly, knocking down apoE after initiation of $A \beta$ seeding did not alter total $A \beta$ levels and resulted in an increase in average plaque size. These findings bring about interesting questions about the biology and dynamic role of apoE in deposition of $A \beta$. 
They also bring to light the challenge of identifying the best age of intervention for an apoE4-lowering therapy. Interestingly, a carrier of a mutation which leads to knockdown of apoE protein was reported in the literature. This was the first apoE null patient to go through extensive cognitive testing and, overall, was largely considered to be normal, suggesting that knockdown of apoE may not be harmful to the brain [66]. However, it was reported that his memory was below what would be considered normal for his age and his language performance was also impaired. Data from apoE KO mice indicate that these mice have age-dependent synaptic loss and cognitive deficits $[67,68]$, however these data could be confounded by the peripheral hyperlipidemia that results from loss of apoE systemically. Interestingly, mice that were deficient in brain apoE specifically did not display deficits in learning and memory, but still showed synaptic loss, similar to total apoE KO [69]. Whether reducing apoE4 expression will have beneficial effects while being safe and tolerable under chronic treatment is a critical question for this approach.

\subsection{Our Perspective}

ApoE4 is the strongest known genetic risk factor for Alzheimer's disease, however, the contributions of apoE to pathology associated with AD are still unclear. Thus, there are many approaches that are being explored in this space that not only differ in modality, but also by mechanism (Figure 2).

Bexarotene, an approved drug for treatment of T-cell lymphoma, was recently tested in a small cohort of AD patients. The goal of the Bexarotene Amyloid Treatment for Alzheimer's Disease (BEAT $\mathrm{AD})$ study was to test whether the preclinical findings that RXR agonism leads to lowering of soluble and insoluble forms of $A \beta$ in mouse models would be recapitulated in AD patients [52]. Interestingly, treatment with bexarotene resulted in a significant decrease in amyloid positivity by positron emission tomography in apoE4 non-carriers compared to the placebo group, though the groups were exceptionally small. No cognitive benefit was observed, presumed to be due to the short duration of the study. ApoE4 carriers observed no benefit from bexarotene treatment. Modulation of apoE lipidation was not an endpoint in the study, thus is it difficult to conclude from these data whether lipidation of apoE was altered and played a role in decreased amyloid deposition. Interestingly, plasma triglyceride levels negatively correlated with cortical $A \beta$ levels in apoE4 non-carriers. Brain exposure of bexarotene was not reported in this study. Another study was published the same year which evaluated $A \beta$ and apoE metabolism with bexarotene treatment in healthy subjects [70]. This phase $\mathrm{Ib}$ study found that brain exposure of orally-dosed bexarotene was in the low $\mathrm{nM}$ range while plasma levels were low $\mu \mathrm{M}$, suggesting low CNS penetration. They reported an increase in CSF apoE but no effect on A $\beta$ metabolism. Lipidation of apoE was not reported due to technical difficulties. Given the hepatic toxicity liability that was demonstrated with LXR $\alpha$ and RXR agonism, identification of an astrocyte-specific mechanism for upregulation of abca1 and apoE lipidation would be advantageous as it would limit associated peripheral toxicity.

Targeting apoE for $\mathrm{AD}$ has the potential to influence many aspects of the pathophysiology of the disease. ApoE has been reported to play a role in clearance of $A \beta$, however, evidence from the literature suggests that the potential beneficial effects of modulation of this protein should not be limited to $A \beta$ clearance. The fundamental role of apoE is to transport lipids. Specifically, apoE is important for delivery of cholesterol to neurons-a cell type which requires cholesterol for maintenance-and for clearance of lipid debris to promote myelin repair. Whether promoting this role of lipidated apoE can be harnessed to improve neuronal function in the disease state has yet to be demonstrated. Interestingly, an LXR agonist has been shown to upregulate abca1 in oligodendrocytes, regulate cholesterol homeostasis and promote remyelination in an animal model [71,72], suggesting that modulation of this mechanistic axis could also be beneficial to demyelination. Furthermore, apoE has been linked to neuroinflammation. ApoE-deficient and apoE4-expressing mice have been shown to have a pro-inflammatory phenotype compared to apoE3 mice after a lipopolysaccharide challenge, demonstrating increased micro- and astro-gliosis and prolonged cytokines production [17]. Additionally, bexarotene treatment in the 
APP/PS1 mice significantly reduced microgliosis in the hippocampus, suggesting that abca1 and apoE lipidation are important for neuroinflammation [73]. ApoE was recently reported to be a "check point" inhibitor of the classical complement cascade in an isoform-dependent manner where apoE4 results were similar to apoE KO [74]. ApoE binds to, and is a proposed ligand for, the triggering receptor expressed on myeloid cells (TREM2) [75,76], a recently identified candidate risk loci for LOAD [77,78]. This interaction likely modulates AD pathology, though it is currently unclear what the role of apoE is in TREM2 biology; the data are reviewed nicely elsewhere [79].

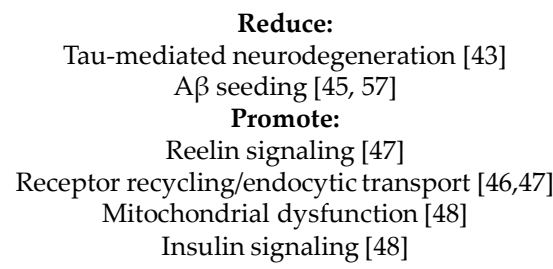

Promote:

Lipid delivery [30]

Neuronal growth [26]

Neuronal survival [32]

Remyelination [71]

Amyloid clearance $[18,19]$

Neuroimmune modulation [17]

Cerebrovascular function [14, 15]
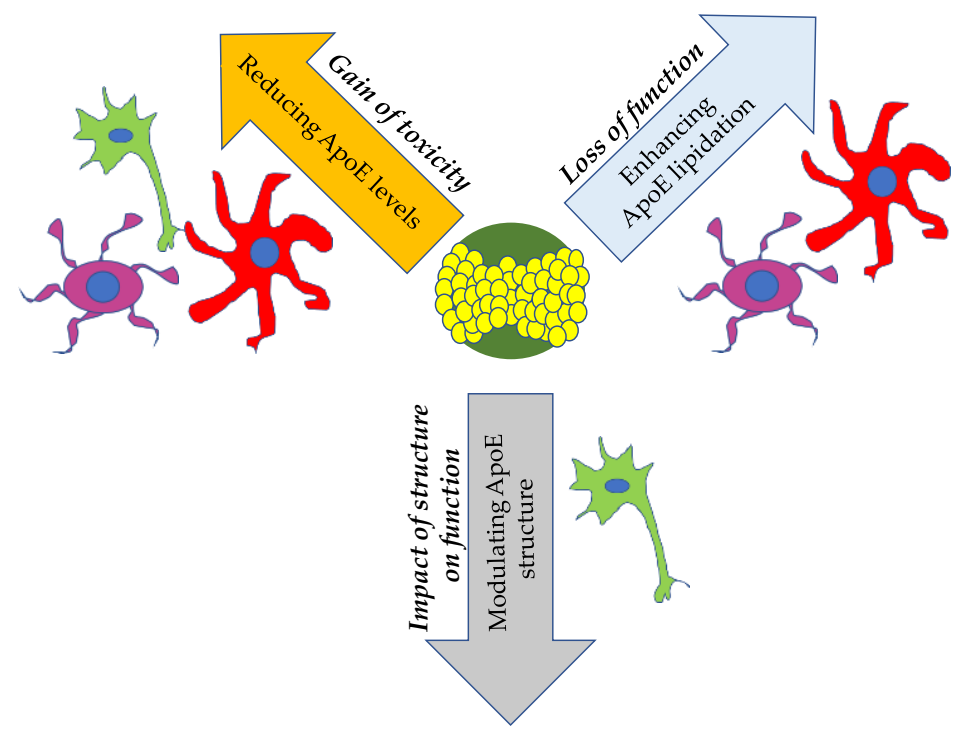

Reduce:

Generation of neurotoxic apoE fragments [38, 39]

Tau phosphorylation [42]

Mitochondrial dysfunction in neurons [41]

GABA-ergic neuronal dysfunction [49]

Figure 2. Multiple hypotheses for targeting apoE and their downstream effects. There are many reported findings in the literature which support the hypotheses (italicized) aimed at unveiling the function of apoE in the brain. The approach for targeting apoE in relation to each hypothesis is listed within the arrow. Cell types involved are astrocytes (red), microglia (purple) and neurons (green). A lipidated apoE particle is depicted in the center.

Although the primary focus of research on brain-derived apoE has been in the AD field, there are more data coming out further exploring the effects of the apoE genotype in cognitively normal people. For instance, there is research on white matter integrity [80] and cerebrovascular reactivity [81], as well as a host of abnormalities reported in apoE knock-in mice, which are reviewed in detail [24]. ApoE biology in the brain is extremely complex with many contradictory findings being reported as to its function and role in the CNS in mice. Therefore, human studies comparing $\varepsilon 4$ carriers and non-carriers are more likely to provide information on the roles of apoE in health and disease. Indeed, imaging studies have suggested that $\varepsilon 4$ carriers have accelerated brain deformations in the Alzheimer's disease neuroimaging initiative (ADNI) cohort $[82,83]$. Interestingly, a recent study conducted in cognitively normal non-carrier, heterozygotes and homozygous $\varepsilon 4$ carriers showed a dose effect on 
hippocampal morphology, with carriers having increased abnormalities in this structure prior to onset of cognitive decline [84]. The results of these studies suggest that having an $\varepsilon 4$ allele is detrimental to maintenance of brain structures that are impacted by AD.

Another area of AD biology that apoE most likely plays a role in is cerebrovascular dysfunction $[85,86]$. The brain is a highly vascularized organ and its high energy demand consumes $20-25 \%$ of the body's oxygen and glucose stores [87]. Blood flow to the brain is required for proper CNS development and is necessary for neuronal viability. Vascular disease was shown to strongly correlate with cognitive dysfunction in AD autopsy samples [88]. Additionally, studies utilizing arterial spin labeling magnetic resonance imaging to assess CBF have reported in the ADNI cohort that deficits occur early in the progression to late onset $\mathrm{AD}$, suggesting that cerebrovascular dysfunction may play a causal role in the development of AD [89]. Interestingly, preclinical data suggest a relationship between the apoE genotype and vascular function, however the mechanisms involved are unclear. Cognitively normal carriers of an apoE4 gene demonstrated impaired cerebrovascular reactivity to hypercapnia assessed by blood-oxygen-level-dependent functional magnetic resonance imaging and transcranial doppler [81,90]. Furthermore, mice expressing human apoE4 have reduced resting CBF [15] and impaired vascular response to neuronal activity (neurovascular coupling) [14]. Blood-brain barrier integrity is also compromised in apoE KO and apoE4 mice [15,91,92]. Lastly, carrying an apoE4 allele leads to increased vascular $A \beta$ deposition [93] and homozygotes were reported to have elevated fibrin(ogen) deposition in A $\beta$ positive vessels [94]. Studies investigating the relationship between apoE and cerebrovascular function are needed to increase our understanding of the role of this protein in vascular dysfunction associated with Alzheimer's disease.

One clear deficit in the field is the lack of understanding of the relationship between lipidation of apoE and disease endpoints. Increasing lipidation of apoE is an attractive target for drug discovery as it targets the fundamental apoE function, namely lipid transport. However, the association of apoE lipidation status in CSF with markers of AD progression, such as total tau protein, phosphorylated tau, $A \beta$ ratio, and cognitive end points has not been assessed in a large, well-characterized cohort of healthy controls and AD patients. Total apoE protein levels are informative, and are reduced in apoE4 carriers, but do not directly address the question of lipidation status. One reason for this critical gap in the field is the lack of high(er) throughput and quantitative assays to assess protein lipidation, although some advancements have been made for apolipoprotein A-I [95]. Detection of "lipid-depleted" apoE in the CSF of a small cohort of patients [22] has also been published and requires centrifugation over a potassium bromide gradient, which is not ideal for screening a large number of samples. Large scale studies will need to be performed in order to define efficacious dosing for drug discovery programs looking to increase lipidation of apoE.

ApoE biology is highly complex and there are many aspects—such as the cellular origin and lipidation state of apoE- that must be considered when targeting this protein for AD. Additionally, which patient population would most greatly benefit from an apoE-directed therapy and at what stage of the disease it would be most effective are two outstanding questions in the field. In our opinion, addressing these gaps will be critical to the development of effective apoE-directed therapeutics. For example, an apoE lipidation approach may be suitable for all apoE genotypes given the potential of the mechanism to be restorative. However, the correlation of apoE lipidation state with disease pathology needs to be determined. Generation of human data in well-characterized patient cohorts will be critical for addressing this gap. On the other hand, apoE4 reducing approaches may be suitable for apoE4 homozygous patients. Furthermore, work done in apoE KO mice and characterization studies in a null human do not take into account the compensation that may occur in the complete absence of this critical protein in the brain, or the effect it may have on CNS lipid metabolism. Additionally, whether perturbation of peripheral lipid homeostasis in the absence of apoE will lead to vascular dysfunction will need to be determined. Thus, it is currently unclear whether reducing apoE expression in the brain would have a negative outcome with respect to safety. Currently, there are no findings 
which suggest that increasing lipidation of endogenous apoE in the brain, including apoE4, would carry a safety risk.

In conclusion, apoE is an attractive and rational target for development of disease modifying-therapies for AD. After age, apoE4 is the strongest known risk factor for this disease, and thus targeting apoE could be relevant for those already showing symptoms of the disease. More research is needed in both academia and industry to further uncover the role of this protein in the brain to answer outstanding questions on how it should be targeted.

Author Contributions: G.L.S., G.R.: Original draft preparation, G.L.S., G.R.: Review and editing.

Acknowledgments: We thank Dominic M. Walsh for review of the manuscript.

Conflicts of Interest: The authors declare no conflict of interest.

\section{References}

1. Selkoe, D.J.; Hardy, J. The amyloid hypothesis of Alzheimer's disease at 25 years. EMBO Mol. Med. 2016, 8, 595-608. [CrossRef] [PubMed]

2. Jadhav, S. A walk through tau therapeutic strategies. Acta Neuropathol. Commun. 2019, 7, 22. [CrossRef] [PubMed]

3. Foley, P. Lipids in Alzheimer's disease: A century-old story. Biochim. Biophys. Acta 2010, 1801, 750-753. [CrossRef]

4. Di Paolo, G.; Kim, T.W. Linking lipids to Alzheimer's disease: Cholesterol and beyond. Nat. Rev. Neurosci. 2011, 12, 284-296. [CrossRef]

5. Dietschy, J.M.; Turley, S.D. Thematic review series: Brain Lipids. Cholesterol metabolism in the central nervous system during early development and in the mature animal. J. Lipid Res. 2004, 45, 1375-1397. [CrossRef] [PubMed]

6. Mahley, R.W. Central Nervous System Lipoproteins: ApoE and Regulation of Cholesterol Metabolism. Arterioscler. Thromb. Vasc. Biol. 2016, 36, 1305-1315. [CrossRef]

7. Leduc, V.; Jasmin-Belanger, S.; Poirier, J. APOE and cholesterol homeostasis in Alzheimer's disease. Trends Mol. Med. 2010, 16, 469-477. [CrossRef]

8. Zhang, Y.; Chen, K.; Sloan, S.A.; Bennett, M.L.; Scholze, A.R.; O'Keeffe, S.; Phatnani, H.P.; Guarnieri, P.; Caneda, C.; Ruderisch, N.; et al. An RNA-sequencing transcriptome and splicing database of glia, neurons, and vascular cells of the cerebral cortex. J. Neurosci. 2014, 34, 11929-11947. [CrossRef]

9. Zhang, Y.; Sloan, S.A.; Clarke, L.E.; Caneda, C.; Plaza, C.A.; Blumenthal, P.D.; Vogel, H.; Steinberg, G.K.; Edwards, M.S.; Li, G.; et al. Purification and Characterization of Progenitor and Mature Human Astrocytes Reveals Transcriptional and Functional Differences with Mouse. Neuron 2016, 89, 37-53. [CrossRef] [PubMed]

10. Huang, Y.; Weisgraber, K.H.; Mucke, L.; Mahley, R.W. Apolipoprotein E: Diversity of cellular origins, structural and biophysical properties, and effects in Alzheimer's disease. J. Mol. Neurosci. 2004, 23, 189-204. [CrossRef]

11. Nathan, B.P. Differential effects of apolipoproteins E3 and E4 on neuronal growth in vitro. Science 1994, 264, 850-852. [CrossRef]

12. Pitas, R.E. Role of apolipoprotein $E$ in modulating neurite outgrowth: Potential effect of intracellular apolipoprotein E. Biochem. Soc. Trans. 1998, 26, 257-262. [CrossRef] [PubMed]

13. Levi, O.; Jongen-Relo, A.L.; Feldon, J.; Roses, A.D.; Michaelson, D.M. ApoE4 impairs hippocampal plasticity isoform-specifically and blocks the environmental stimulation of synaptogenesis and memory. Neurobiol. Dis. 2003, 13, 273-282. [CrossRef]

14. Koizumi, K.; Hattori, Y.; Ahn, S.J.; Buendia, I.; Ciacciarelli, A.; Uekawa, K.; Wang, G.; Hiller, A.; Zhao, L.; Voss, H.U.; et al. Apoepsilon4 disrupts neurovascular regulation and undermines white matter integrity and cognitive function. Nat. Commun. 2018, 9, 3816. [CrossRef] [PubMed]

15. Bell, R.D.; Winkler, E.A.; Singh, I.; Sagare, A.P.; Deane, R.; Wu, Z.; Holtzman, D.M.; Betsholtz, C.; Armulik, A.; Sallstrom, J.; et al. Apolipoprotein E controls cerebrovascular integrity via cyclophilin A. Nature 2012, 485, 512-516. [CrossRef] [PubMed]

16. Tensaouti, Y.; Stephanz, E.P.; Yu, T.S.; Kernie, S.G. ApoE Regulates the Development of Adult Newborn Hippocampal Neurons. eNeuro 2018, 5. [CrossRef] 
17. Zhu, Y.; Nwabuisi-Heath, E.; Dumanis, S.B.; Tai, L.M.; Yu, C.; Rebeck, G.W.; LaDu, M.J. APOE genotype alters glial activation and loss of synaptic markers in mice. Glia 2012,60, 559-569. [CrossRef]

18. Riddell, D.R.; Zhou, H.; Comery, T.A.; Kouranova, E.; Lo, C.F.; Warwick, H.K.; Ring, R.H.; Kirksey, Y.; Aschmies, S.; Xu, J.; et al. The LXR agonist TO901317 selectively lowers hippocampal Abeta42 and improves memory in the Tg2576 mouse model of Alzheimer's disease. Mol. Cell Neurosci. 2007, 34, 621-628. [CrossRef]

19. Cramer, P.E.; Cirrito, J.R.; Wesson, D.W.; Lee, C.Y.; Karlo, J.C.; Zinn, A.E.; Casali, B.T.; Restivo, J.L.; Goebel, W.D.; James, M.J.; et al. ApoE-directed therapeutics rapidly clear beta-amyloid and reverse deficits in AD mouse models. Science 2012, 335, 1503-1506. [CrossRef]

20. Liu, C.C.; Liu, C.C.; Kanekiyo, T.; Xu, H.; Bu, G. Apolipoprotein E and Alzheimer disease: Risk, mechanisms and therapy. Nat. Rev. Neurol. 2013, 9, 106-118. [CrossRef]

21. Cruchaga, C.; Kauwe, J.S.; Nowotny, P.; Bales, K.; Pickering, E.H.; Mayo, K.; Bertelsen, S.; Hinrichs, A.; Alzheimer's Disease Neuroimaging, I.; Fagan, A.M.; et al. Cerebrospinal fluid APOE levels: An endophenotype for genetic studies for Alzheimer's disease. Hum. Mol. Genet. 2012, 21, 4558-4571. [CrossRef] [PubMed]

22. Hanson, A.J.; Bayer-Carter, J.L.; Green, P.S.; Montine, T.J.; Wilkinson, C.W.; Baker, L.D.; Watson, G.S.; Bonner, L.M.; Callaghan, M.; Leverenz, J.B.; et al. Effect of apolipoprotein E genotype and diet on apolipoprotein E lipidation and amyloid peptides: Randomized clinical trial. JAMA Neurol. 2013, 70, 972-980. [CrossRef] [PubMed]

23. Sullivan, P.M.; Han, B.; Liu, F.; Mace, B.E.; Ervin, J.F.; Wu, S.; Koger, D.; Paul, S.; Bales, K.R. Reduced levels of human apoE4 protein in an animal model of cognitive impairment. Neurobiol. Aging 2011, 32, 791-801. [CrossRef]

24. Rebeck, G.W. The role of APOE on lipid homeostasis and inflammation in normal brains. J. Lipid Res. 2017, 58, 1493-1499. [CrossRef] [PubMed]

25. Wahrle, S.E.; Jiang, H.; Parsadanian, M.; Legleiter, J.; Han, X.; Fryer, J.D.; Kowalewski, T.; Holtzman, D.M. ABCA1 is required for normal central nervous system ApoE levels and for lipidation of astrocyte-secreted apoE. J. Biol. Chem. 2004, 279, 40987-40993. [CrossRef] [PubMed]

26. Fitz, N.F.; Carter, A.Y.; Tapias, V.; Castranio, E.L.; Kodali, R.; Lefterov, I.; Koldamova, R. ABCA1 Deficiency Affects Basal Cognitive Deficits and Dendritic Density in Mice. J. Alzheimer's Dis. 2017, 56, 1075-1085. [CrossRef] [PubMed]

27. Wahrle, S.E.; Jiang, H.; Parsadanian, M.; Hartman, R.E.; Bales, K.R.; Paul, S.M.; Holtzman, D.M. Deletion of Abca1 increases Abeta deposition in the PDAPP transgenic mouse model of Alzheimer disease. J. Biol. Chem. 2005, 280, 43236-43242. [CrossRef]

28. Nordestgaard, L.T.; Tybjaerg-Hansen, A.; Nordestgaard, B.G.; Frikke-Schmidt, R. Loss-of-function mutation in ABCA1 and risk of Alzheimer's disease and cerebrovascular disease. Alzheimer's Dement. 2015, 11, 1430-1438. [CrossRef]

29. Wahrle, S.E.; Jiang, H.; Parsadanian, M.; Kim, J.; Li, A.; Knoten, A.; Jain, S.; Hirsch-Reinshagen, V.; Wellington, C.L.; Bales, K.R.; et al. Overexpression of ABCA1 reduces amyloid deposition in the PDAPP mouse model of Alzheimer disease. J. Clin. Investig. 2008, 118, 671-682. [CrossRef]

30. Namjoshi, D.R.; Martin, G.; Donkin, J.; Wilkinson, A.; Stukas, S.; Fan, J.; Carr, M.; Tabarestani, S.; Wuerth, K.; Hancock, R.E.; et al. The liver X receptor agonist GW3965 improves recovery from mild repetitive traumatic brain injury in mice partly through apolipoprotein E. PLOS ONE 2013, 8, e53529. [CrossRef]

31. Loane, D.J.; Washington, P.M.; Vardanian, L.; Pocivavsek, A.; Hoe, H.S.; Duff, K.E.; Cernak, I.; Rebeck, G.W.; Faden, A.I.; Burns, M.P. Modulation of ABCA1 by an LXR agonist reduces beta-amyloid levels and improves outcome after traumatic brain injury. J. Neurotr. 2011, 28, 225-236. [CrossRef]

32. Zhao, J.; Davis, M.D.; Martens, Y.A.; Shinohara, M.; Graff-Radford, N.R.; Younkin, S.G.; Wszolek, Z.K.; Kanekiyo, T.; Bu, G. APOE epsilon4/epsilon4 diminishes neurotrophic function of human iPSC-derived astrocytes. Hum. Mol. Genet. 2017, 26, 2690-2700. [CrossRef] [PubMed]

33. Robert, J.; Stukas, S.; Button, E.; Cheng, W.H.; Lee, M.; Fan, J.; Wilkinson, A.; Kulic, I.; Wright, S.D.; Wellington, C.L. Reconstituted high-density lipoproteins acutely reduce soluble brain Abeta levels in symptomatic APP/PS1 mice. Biochim. Biophys. Acta 2016, 1862, 1027-1036. [CrossRef]

34. Stukas, S.; Robert, J.; Wellington, C.L. High-density lipoproteins and cerebrovascular integrity in Alzheimer's disease. Cell Metab. 2014, 19, 574-591. [CrossRef] [PubMed] 
35. Liu, D.S.; Pan, X.D.; Zhang, J.; Shen, H.; Collins, N.C.; Cole, A.M.; Koster, K.P.; Ben Aissa, M.; Dai, X.M.; Zhou, M.; et al. APOE4 enhances age-dependent decline in cognitive function by down-regulating an NMDA receptor pathway in EFAD-Tg mice. Mol. Neurodegener. 2015, 10, 7. [CrossRef]

36. Horsburgh, K.; Nicoll, J.A. Selective alterations in the cellular distribution of apolipoprotein E immunoreactivity following transient cerebral ischaemia in the rat. Neuropathol. Appl. Neurobiol. 1996, 22, 342-349. [CrossRef] [PubMed]

37. Xu, Q.; Bernardo, A.; Walker, D.; Kanegawa, T.; Mahley, R.W.; Huang, Y. Profile and regulation of apolipoprotein $\mathrm{E}$ (ApoE) expression in the CNS in mice with targeting of green fluorescent protein gene to the ApoE locus. J. Neurosci. 2006, 26, 4985-4994. [CrossRef] [PubMed]

38. Huang, Y.; Liu, X.Q.; Wyss-Coray, T.; Brecht, W.J.; Sanan, D.A.; Mahley, R.W. Apolipoprotein E fragments present in Alzheimer's disease brains induce neurofibrillary tangle-like intracellular inclusions in neurons. Proc. Natl. Acad. Sci. USA 2001, 98, 8838-8843. [CrossRef]

39. Harris, F.M.; Brecht, W.J.; Xu, Q.; Tesseur, I.; Kekonius, L.; Wyss-Coray, T.; Fish, J.D.; Masliah, E.; Hopkins, P.C.; Scearce-Levie, K.; et al. Carboxyl-terminal-truncated apolipoprotein E4 causes Alzheimer's disease-like neurodegeneration and behavioral deficits in transgenic mice. Proc. Natl. Acad. Sci. USA 2003, 100, 10966-10971. [CrossRef] [PubMed]

40. Mahley, R.W.; Huang, Y.; Weisgraber, K.H. Detrimental effects of apolipoprotein E4: Potential therapeutic targets in Alzheimer's disease. Curr. Alzheimer Res. 2007, 4, 537-540. [CrossRef] [PubMed]

41. Mahley, R.W.; Weisgraber, K.H.; Huang, Y. Apolipoprotein E4: A causative factor and therapeutic target in neuropathology, including Alzheimer's disease. Proc. Natl. Acad. Sci. USA 2006, 103, 5644-5651. [CrossRef]

42. Brecht, W.J.; Harris, F.M.; Chang, S.; Tesseur, I.; Yu, G.Q.; Xu, Q.; Dee Fish, J.; Wyss-Coray, T.; Buttini, M.; Mucke, L.; et al. Neuron-specific apolipoprotein e4 proteolysis is associated with increased tau phosphorylation in brains of transgenic mice. J. Neurosci. 2004, 24, 2527-2534. [CrossRef] [PubMed]

43. Shi, Y.; Yamada, K.; Liddelow, S.A.; Smith, S.T.; Zhao, L.; Luo, W.; Tsai, R.M.; Spina, S.; Grinberg, L.T.; Rojas, J.C.; et al. ApoE4 markedly exacerbates tau-mediated neurodegeneration in a mouse model of tauopathy. Nature 2017, 549, 523-527. [CrossRef] [PubMed]

44. Strickland, M.R.; Holtzman, D.M. Dr. Jekyll and Mr. Hyde: ApoE explains opposing effects of neuronal LRP1. J. Clin. Investig. 2019. [CrossRef] [PubMed]

45. Liu, C.C.; Zhao, N.; Fu, Y.; Wang, N.; Linares, C.; Tsai, C.W.; Bu, G. ApoE4 Accelerates Early Seeding of Amyloid Pathology. Neuron 2017, 96, 1024-1032. [CrossRef] [PubMed]

46. Xian, X.; Pohlkamp, T.; Durakoglugil, M.S.; Wong, C.H.; Beck, J.K.; Lane-Donovan, C.; Plattner, F.; Herz, J. Reversal of ApoE4-induced recycling block as a novel prevention approach for Alzheimer's disease. eLife 2018, 7. [CrossRef] [PubMed]

47. Chen, Y.; Durakoglugil, M.S.; Xian, X.; Herz, J. ApoE4 reduces glutamate receptor function and synaptic plasticity by selectively impairing ApoE receptor recycling. Proc. Natl. Acad. Sci. USA 2010, 107, 12011-12016. [CrossRef]

48. Zhao, N.; Liu, C.C.; Van Ingelgom, A.J.; Martens, Y.A.; Linares, C.; Knight, J.A.; Painter, M.M.; Sullivan, P.M.; $\mathrm{Bu}, \mathrm{G}$. Apolipoprotein E4 Impairs Neuronal Insulin Signaling by Trapping Insulin Receptor in the Endosomes. Neuron 2017, 96, 115-129.e5. [CrossRef]

49. Knoferle, J.; Yoon, S.Y.; Walker, D.; Leung, L.; Gillespie, A.K.; Tong, L.M.; Bien-Ly, N.; Huang, Y. Apolipoprotein E4 produced in GABAergic interneurons causes learning and memory deficits in mice. J. Neurosci. 2014, 34, 14069-14078. [CrossRef]

50. Chung, W.S.; Verghese, P.B.; Chakraborty, C.; Joung, J.; Hyman, B.T.; Ulrich, J.D.; Holtzman, D.M.; Barres, B.A. Novel allele-dependent role for APOE in controlling the rate of synapse pruning by astrocytes. Proc. Natl. Acad. Sci. USA 2016, 113, 10186-10191. [CrossRef]

51. Yamazaki, Y.; Painter, M.M.; Bu, G.; Kanekiyo, T. Apolipoprotein E as a Therapeutic Target in Alzheimer's Disease: A Review of Basic Research and Clinical Evidence. CNS Drugs 2016, 30, 773-789. [CrossRef]

52. Cummings, J.L.; Zhong, K.; Kinney, J.W.; Heaney, C.; Moll-Tudla, J.; Joshi, A.; Pontecorvo, M.; Devous, M.; Tang, A.; Bena, J. Double-blind, placebo-controlled, proof-of-concept trial of bexarotene Xin moderate Alzheimer's disease. Alzheimer's Res. Ther. 2016, 8, 4. [CrossRef]

53. Boehm-Cagan, A.; Bar, R.; Liraz, O.; Bielicki, J.K.; Johansson, J.O.; Michaelson, D.M. ABCA1 Agonist Reverses the ApoE4-Driven Cognitive and Brain Pathologies. J. Alzheimer's Dis. 2016, 54, 1219-1233. [CrossRef] [PubMed] 
54. Wang, C.; Najm, R.; Xu, Q.; Jeong, D.E.; Walker, D.; Balestra, M.E.; Yoon, S.Y.; Yuan, H.; Li, G.; Miller, Z.A.; et al. Gain of toxic apolipoprotein E4 effects in human iPSC-derived neurons is ameliorated by a small-molecule structure corrector. Nat. Med. 2018. [CrossRef] [PubMed]

55. Mahley, R.W.; Huang, Y. Small-molecule structure correctors target abnormal protein structure and function: Structure corrector rescue of apolipoprotein E4-associated neuropathology. J. Med. Chem. 2012, 55, 8997-9008. [CrossRef] [PubMed]

56. Liao, F.; Li, A.; Xiong, M.; Bien-Ly, N.; Jiang, H.; Zhang, Y.; Finn, M.B.; Hoyle, R.; Keyser, J.; Lefton, K.B.; et al. Targeting of nonlipidated, aggregated apoE with antibodies inhibits amyloid accumulation. J. Clin. Investig. 2018. [CrossRef]

57. Huynh, T.V.; Liao, F.; Francis, C.M.; Robinson, G.O.; Serrano, J.R.; Jiang, H.; Roh, J.; Finn, M.B.; Sullivan, P.M.; Esparza, T.J.; et al. Age-Dependent Effects of apoE Reduction Using Antisense Oligonucleotides in a Model of beta-amyloidosis. Neuron 2017, 96, 1013-1023.e4. [CrossRef]

58. Zhong, N.; Weisgraber, K.H. Understanding the basis for the association of apoE4 with Alzheimer's disease: Opening the door for therapeutic approaches. Curr. Alzheimer Res. 2009, 6, 415-418. [CrossRef]

59. Ramaswamy, G.; Xu, Q.; Huang, Y.; Weisgraber, K.H. Effect of domain interaction on apolipoprotein E levels in mouse brain. J. Neurosci. 2005, 25, 10658-10663. [CrossRef]

60. Riddell, D.R. Impact of apolipoprotein E (ApoE) polymorphism on brain ApoE levels. J. Neurosci. 2008, 28, 11445-11453. [CrossRef]

61. Fitz, N.F.; Castranio, E.L.; Carter, A.Y.; Kodali, R.; Lefterov, I.; Koldamova, R. Improvement of memory deficits and amyloid-beta clearance in aged APP23 mice treated with a combination of anti-amyloid-beta antibody and LXR agonist. J. Alzheimer's Dis. 2014, 41, 535-549. [CrossRef] [PubMed]

62. Corona, A.W.; Kodoma, N.; Casali, B.T.; Landreth, G.E. ABCA1 is Necessary for Bexarotene-Mediated Clearance of Soluble Amyloid Beta from the Hippocampus of APP/PS1 Mice. J. Neuroimmune Pharmacol. 2016, 11, 61-72. [CrossRef]

63. Schultz, J.R.; Tu, H.; Luk, A.; Repa, J.J.; Medina, J.C.; Li, L.; Schwendner, S.; Wang, S.; Thoolen, M.; Mangelsdorf, D.J.; et al. Role of LXRs in control of lipogenesis. Genes Dev. 2000, 14, 2831-2838. [CrossRef] [PubMed]

64. Dresselhaus, E.; Duerr, J.M.; Vincent, F.; Sylvain, E.K.; Beyna, M.; Lanyon, L.F.; LaChapelle, E.; Pettersson, M.; Bales, K.R.; Ramaswamy, G. Class I HDAC inhibition is a novel pathway for regulating astrocytic apoE secretion. PLoS ONE 2018, 13, e0194661. [CrossRef] [PubMed]

65. Fan, J.; Zareyan, S.; Zhao, W.; Shimizu, Y.; Pfeifer, T.A.; Tak, J.H.; Isman, M.B.; Van den Hoven, B.; Duggan, M.E.; Wood, M.W.; et al. Identification of a Chrysanthemic Ester as an Apolipoprotein E Inducer in Astrocytes. PLoS ONE 2016, 11, e0162384. [CrossRef] [PubMed]

66. Mak, A.C.; Pullinger, C.R.; Tang, L.F.; Wong, J.S.; Deo, R.C.; Schwarz, J.M.; Gugliucci, A.; Movsesyan, I.; Ishida, B.Y.; Chu, C.; et al. Effects of the absence of apolipoprotein e on lipoproteins, neurocognitive function, and retinal function. JAMA Neurol. 2014, 71, 1228-1236. [CrossRef] [PubMed]

67. Veinbergs, I.; Mallory, M.; Sagara, Y.; Masliah, E. Vitamin E supplementation prevents spatial learning deficits and dendritic alterations in aged apolipoprotein E-deficient mice. Eur. J. Neurosci. 2000, 12, 4541-4546. [PubMed]

68. Masliah, E.; Mallory, M.; Ge, N.; Alford, M.; Veinbergs, I.; Roses, A.D. Neurodegeneration in the central nervous system of apoE-deficient mice. Exp.Neurol. 1995, 136, 107-122. [CrossRef]

69. Lane-Donovan, C.; Wong, W.M.; Durakoglugil, M.S.; Wasser, C.R.; Jiang, S.; Xian, X.; Herz, J. Genetic Restoration of Plasma ApoE Improves Cognition and Partially Restores Synaptic Defects in ApoE-Deficient Mice. J. Neurosci. 2016, 36, 10141-10150. [CrossRef]

70. Ghosal, K.; Haag, M.; Verghese, P.B.; West, T.; Veenstra, T.; Braunstein, J.B.; Bateman, R.J.; Holtzman, D.M.; Landreth, G.E. A randomized controlled study to evaluate the effect of bexarotene on amyloid-beta and apolipoprotein E metabolism in healthy subjects. Alzheimer's Dement. 2016, 2, 110-120.

71. Cantuti-Castelvetri, L.; Fitzner, D.; Bosch-Queralt, M.; Weil, M.T.; Su, M.; Sen, P.; Ruhwedel, T.; Mitkovski, M.; Trendelenburg, G.; Lutjohann, D.; et al. Defective cholesterol clearance limits remyelination in the aged central nervous system. Science 2018, 359, 684-688. [CrossRef] [PubMed]

72. Nelissen, K. Liver $X$ receptors regulate cholesterol homeostasis in oligodendrocytes. J. Neurosci. Res. 2012, 90, 60-71. [CrossRef] 
73. Casali, B.T.; Reed-Geaghan, E.G.; Landreth, G.E. Nuclear receptor agonist-driven modification of inflammation and amyloid pathology enhances and sustains cognitive improvements in a mouse model of Alzheimer's disease. J. Neuroinflamm. 2018, 15, 43. [CrossRef]

74. Yin, C. ApoE attenuates unresolvable inflammation by complex formation with activated C1q. Nat. Med. 2019, 25, 496-506. [CrossRef] [PubMed]

75. Bailey, C.C.; DeVaux, L.B.; Farzan, M. The Triggering Receptor Expressed on Myeloid Cells 2 Binds Apolipoprotein E. J. Biol. Chem. 2015, 290, 26033-26042. [CrossRef]

76. Atagi, Y. Apolipoprotein E Is a Ligand for Triggering Receptor Expressed on Myeloid Cells 2 (TREM2). J. Biol. Chem. 2015, 290, 26043-26050. [CrossRef]

77. Guerreiro, R.; Wojtas, A.; Bras, J.; Carrasquillo, M.; Rogaeva, E.; Majounie, E.; Cruchaga, C.; Sassi, C.; Kauwe, J.S.; Younkin, S.; et al. TREM2 variants in Alzheimer's disease. N. Engl. J. Med. 2013, 368, 117-127. [CrossRef] [PubMed]

78. Jonsson, T.; Stefansson, H.; Steinberg, S.; Jonsdottir, I.; Jonsson, P.V.; Snaedal, J.; Bjornsson, S.; Huttenlocher, J.; Levey, A.I.; Lah, J.J.; et al. Variant of TREM2 associated with the risk of Alzheimer's disease. N. Engl. J. Med. 2013, 368, 107-116. [CrossRef] [PubMed]

79. Wolfe, C.M.; Fitz, N.F.; Nam, K.N.; Lefterov, I.; Koldamova, R. The Role of APOE and TREM2 in Alzheimer's Disease-Current Understanding and Perspectives. Int. J. Mol. Sci. 2018, 20. [CrossRef] [PubMed]

80. Operto, G.; Cacciaglia, R.; Grau-Rivera, O.; Falcon, C.; Brugulat-Serrat, A.; Rodenas, P.; Ramos, R.; Moran, S.; Esteller, M.; Bargallo, N.; et al. White matter microstructure is altered in cognitively normal middle-aged APOE-epsilon4 homozygotes. Alzheimer's Res. Ther. 2018, 10, 48. [CrossRef] [PubMed]

81. Suri, S.; Mackay, C.E.; Kelly, M.E.; Germuska, M.; Tunbridge, E.M.; Frisoni, G.B.; Matthews, P.M.; Ebmeier, K.P.; Bulte, D.P.; Filippini, N. Reduced cerebrovascular reactivity in young adults carrying the APOE epsilon4 allele. Alzheimer's Dement. 2015, 11, 648-657. [CrossRef] [PubMed]

82. Shi, J.; Lepore, N.; Gutman, B.A.; Thompson, P.M.; Baxter, L.C.; Caselli, R.J.; Wang, Y.; Alzheimer's Disease Neuroimaging, I. Genetic influence of apolipoprotein E4 genotype on hippocampal morphometry: An N=725 surface-based Alzheimer's disease neuroimaging initiative study. Hum. Brain Map. 2014, 35, 3903-3918. [CrossRef]

83. Li, B.; Shi, J.; Gutman, B.A.; Baxter, L.C.; Thompson, P.M.; Caselli, R.J.; Wang, Y.; Alzheimer's Disease Neuroimaging, I. Influence of APOE Genotype on Hippocampal Atrophy over Time - An N=1925 Surface-Based ADNI Study. PLoS ONE 2016, 11, e0152901. [CrossRef] [PubMed]

84. Dong, Q.; Zhang, W.; Wu, J.; Li, B.; Schron, E.H.; McMahon, T.; Shi, J.; Gutman, B.A.; Chen, K.; Baxter, L.C.; et al. Applying surface-based hippocampal morphometry to study APOE-E4 allele dose effects in cognitively unimpaired subjects. NeuroImage Clin. 2019, 22, 101744. [CrossRef]

85. Strickland, S. Blood will out: Vascular contributions to Alzheimer's disease. J. Clin. Investig. 2018, 128, 556-563. [CrossRef] [PubMed]

86. Bell, R.D.; Zlokovic, B.V. Neurovascular mechanisms and blood-brain barrier disorder in Alzheimer's disease. Acta Neuropathol. 2009, 118, 103-113. [CrossRef]

87. Sweeney, M.D.; Sagare, A.P.; Zlokovic, B.V. Blood-brain barrier breakdown in Alzheimer disease and other neurodegenerative disorders. Nat. Rev. Neurol. 2018, 14, 133-150. [CrossRef]

88. Serrano-Pozo, A.; Qian, J.; Monsell, S.E.; Frosch, M.P.; Betensky, R.A.; Hyman, B.T. Examination of the clinicopathologic continuum of Alzheimer disease in the autopsy cohort of the National Alzheimer Coordinating Center. J. Neuropathol. Exp. Neurol. 2013, 72, 1182-1192. [CrossRef] [PubMed]

89. Iturria-Medina, Y.; Sotero, R.C.; Toussaint, P.J.; Mateos-Perez, J.M.; Evans, A.C.; Alzheimer's Disease Neuroimaging, I. Early role of vascular dysregulation on late-onset Alzheimer's disease based on multifactorial data-driven analysis. Nat. Commun. 2016, 7, 11934. [CrossRef] [PubMed]

90. Hajjar, I.; Sorond, F.; Lipsitz, L.A. Apolipoprotein E, carbon dioxide vasoreactivity, and cognition in older adults: Effect of hypertension. J. Am. Geriatr. Soc. 2015, 63, 276-281. [CrossRef] [PubMed]

91. Hafezi-Moghadam, A.; Thomas, K.L.; Wagner, D.D. ApoE deficiency leads to a progressive age-dependent blood-brain barrier leakage. Am. J. Physiol. 2007, 292, C1256-C1262. [CrossRef] [PubMed]

92. Methia, N.; Andre, P.; Hafezi-Moghadam, A.; Economopoulos, M.; Thomas, K.L.; Wagner, D.D. ApoE deficiency compromises the blood brain barrier especially after injury. Mol. Med. 2001, 7, 810-815. [CrossRef] 
93. Peuralinna, T.; Tanskanen, M.; Makela, M.; Polvikoski, T.; Paetau, A.; Kalimo, H.; Sulkava, R.; Hardy, J.; Lai, S.L.; Arepalli, S.; et al. APOE and AbetaPP gene variation in cortical and cerebrovascular amyloid-beta pathology and Alzheimer's disease: A population-based analysis. J. Alzheimer's Dis. 2011, 26, 377-385. [CrossRef] [PubMed]

94. Hultman, K.; Strickland, S.; Norris, E.H. The APOE varepsilon4/varepsilon4 genotype potentiates vascular fibrin(ogen) deposition in amyloid-laden vessels in the brains of Alzheimer's disease patients. J. Cereb. Blood Flow Metab. 2013, 33, 1251-1258. [CrossRef] [PubMed]

95. Niedziela-Majka, A.; Lad, L.; Chisholm, J.W.; Lagpacan, L.; Schwartz, K.; Hung, M.; Jin, D.; Fung, W.; Brendza, K.M.; Liu, X.; et al. Lipid-sensing high-throughput ApoA-I assays. J. Biomol. Screen. 2012, 17, 1050-1061. [CrossRef] [PubMed]

(C) 2019 by the authors. Licensee MDPI, Basel, Switzerland. This article is an open access article distributed under the terms and conditions of the Creative Commons Attribution (CC BY) license (http://creativecommons.org/licenses/by/4.0/). 